\title{
Gender Roles in Politics: A Comparative Study Between Indonesia and India
}

\author{
Vina Salviana Darvina Soedarwo ${ }^{1}$, Nurul Zuriah ${ }^{2}$, Gonda Yumitro ${ }^{3}$, Gautam Kumar Jha \\ \{vina_salviana@yahoo.co.id, zuriahnurul@gmail.com, yumitro@gmail.com, \\ gautamkjha@mail.jnu.ac.in\}
}

University of Muhammadiyah Malang-Indonesia ${ }^{123}$, Jawaharlal Nehru University-India ${ }^{4}$

\begin{abstract}
In the process of democratisation, the matter of greater political participation of women and representativeness became a prerequisite of the realisation of more meaningful democracy. The more meaningful democracy was the democracy that paid attention to and struggled the interests of the majority of the people, namely women, in particular country such as in Indonesia. This condition also happened in India, where one of the indicators of participation of women in political parties was measured from the representation of women in the parliament under the quota, similar with Indonesia. According to this comparative study research, the low number of women participation in India caused by women still feel more convenience to stay domestically in private place and the domination of power structure. However, in Indonesia caused less support from parties, such as limited financial support for female candidates, limited access to political networks and prevalence of double standards. The role of men in politics was still dominant in these two countries. An alternative solution was supporting program to advance gender equality in politics through social media net working.
\end{abstract}

Keyword: Gender Roles, Politics, Indonesia, India

\section{Introduction}

The gender of women is always marginalised, and the role of women in gender is always limited in secondary status due to patriarchal culture. This patriarchal culture occurs almost everywhere in Indonesia. The paternal culture provides an opportunity or access to dominant male gender so that the presence of women is marginalised, one of the participation of women in political life, although, in some provinces of Indonesia, the female gender accesses successfully to the opportunity to become the leading executive company. It has a much better role in the executive branch and the legislature.

Similarly, the conditions in India as a democratic state. The Constitution guarantees all citizens the right to participate in the democratic process but, at the same time, compares the social and economic reality of India with the problem of inequality and social inequality resulting from the sex, class differences, the subordination of women to men, poverty and parental domination. As a democratic country, India has an independent electoral commission mandated by the Constitution, in addition to a women's committee formed by the central government [1]

In democratic countries, quotas are an essential mechanism to achieve greater representation of women in political processes and as a means to ensure that women's political interests are voiced and representative. Empowerment classes are positive steps as an integral part of the debate on the development of a democratic political system based on the principle of gender equality. The demand for a quota is an integral part of the higher demand for rights for women in politics. Similarly, in Indonesia in the age of reform and gender equality in opportunities and advantages to achieve equality and justice under Article $28(\mathrm{H})$ (2) of the 
1945 Law on Political Parties and the interest in the politics and opportunities of the government, this law could not change the behavior of society in politics. So, the expected proportion of women was not reached.

In India, political maps are divided into 543 parliamentary districts. Each circle is represented by a member of Parliament sitting on the Lok Sabha (lower table). The form and size of the parliamentary constituency are determined by an independent commission called the Boundary Commission. This commission will take into account the population, geography, state and administrative limits. The system of reserves or quotas for women was developed along with the activities of the women's movement in India, which finally succeeded in establishing seats for women in local institutions imposing by the constitution to increase the participation of women in a local institution such as in village level. In 1988, a national committee called the National Perspective (NDP) was created to demand a $30 \%$ increase in the political participation of women in legislative bodies [2]

From the description of these two countries it can be seen that in both Indonesia and India, gender equality efforts have been made in the form of affirmative action [3] to increase the number of women's roles as parliamentarians. The role of women in politics has not been in line with expectations, so it is important to examine the role of women in Indonesia compared to women in the Indian state, which seems to be a democratic state first.

\section{Gender Roles in Politics}

\subsection{Women Representative in Indonesian Parliament}

The differences in political behaviours of women and men at the ordinary people or political elites are explained through the history of the socialisation, namely how women learn from proper sex roles in the field of politics. In Indonesia, the constraint of the socialisation between women and men in the political roles starts from the family, for instance, whether there is a value representing that the roles in a political field tend to be more suitable/proper for men rather women. The patriarchy ideology [4] still colours the people living in Indonesia from the family, then develops into political parties wherein a "masculine model" in the political arena men are still very dominant in making political rules and mostly in defining the standard of evaluation.

Moreover, political life is often arranged in line with norms and values of men and a particular case, even with the lifestyle of men, for example, the political model based on the idea of the "loser and winner", competition and confrontation, instead of respect one another, collaboration and consensus. This environment is often in contradiction with women, refusing the politics as a whole or even the political style of men.

Differences between men and women also arise in the content and priority in making decisions determined based on interests, backgrounds and work patterns of the two sexes. Women tend to give priorities to social problems, such as social assurance, health services and issues on children and women.

The men-dominated work patterns are then reflected in the work schedules of parliament members which are often characterised by a weak structure to support working mothers in general and especially women parliament members. Women show flexibility and hard work, besides doing activities in their parties and constituents, they should also help various committees, work networks with women in their parties and the multi-parties level, and also with women out of the parliament. Dealing with the constraint where women still show minor mental state, the mental state giving more emphasis on activities in the domestic sector also makes their position difficult. For more details, the following table 1 describes the journey of 
the representation of women in Parliament of legislative election results in the Reformation era.

Table 1. The Members of the House of Representatives Based on Women Members Won of the General Election in Reformation Era

\begin{tabular}{lccc}
\hline Year & $\begin{array}{c}\text { Total No of Seats } \\
\text { (Election Held) }\end{array}$ & $\begin{array}{c}\text { No. of Women } \\
\text { Members Won }\end{array}$ & $\begin{array}{c}\text { \% of the Total } \\
\text { Women Members }\end{array}$ \\
\hline 1999 & 500 & 44 & 8.8 \\
2004 & 550 & 65 & 11.82 \\
2009 & 560 & 100 & 17.86 \\
2014 & 560 & 97 & 17.32 \\
\hline Source: General Election Commissions (quoted from Indonesian Statistic Publication 2015)
\end{tabular}

In Indonesia general election of 2014, out of a total 560 seats of the Parliament, there were only 97 women members. A similar thing happened in the elections of 2009, where the number of women in Parliament just reached 100 people. Women's representation in this legislative area even experienced a decline from the position of 17.86 per cent (2009) to 17.32 per cent (2014), although the reformation in Indonesia wants to make democracy better including about gender equality in various fields including politics.

\subsection{Women Representative in Indian Parliament}

The women's movement and gender politics in India is currently divided over the question of affirmative action for women in parliament and state legislatures There are two main issues: first, the issue of overlapping quotas for women in the general category and those in backward caste communities and second, the issue of elitism. So, affirmative action for women in legislative bodies is the need of the hour as it would go a long way in removing obstacles that inhibit their participation. It would bridge the wide men-women gap in the electoral set-up and pave the way for gender-inclusive electoral politics [5].

In India women participation in politics related to the kind of tradition. However, there were also some women figures in Indian politics, such as Sonia Gandhi but it is not the products of the system concerning on gender. Right now, there are more women are involving politics in India, so, their participation in political parties increases. One statement of the informant (women politician) said that "equality is not really", because there are still men domination in Indian politics. However, their opportunity in various other public sectors is better since there are many women become workers and traders. Moreover, the highest participation of women in Indian politics is at the level of panchayat (villages). In India, the participation of women is still also lacking, under the quota, since the women still feel more convenience to stay domestically in private place.

In the elections of 2014, out of a total 543 seats of the Parliament, there were only 61 women members. A similar thing happened in the elections of 2009 , where the number of women in Parliament just reached 59 people. Women's representation in this legislative area increases from the position of 10.9 per cent (2009) to 11.2 per cent (2014), but still below of the quota. For more details, the following table 2 describes the journey of the representation of women in Parliament of legislative election results in India. 
Table 2. Representation of Women in Lok Sabha

\begin{tabular}{lccc}
\hline Year & $\begin{array}{c}\text { Total No of Seats } \\
\text { (Election Held) }\end{array}$ & $\begin{array}{c}\text { No of Women } \\
\text { Members Won }\end{array}$ & $\begin{array}{c}\text { \% of the Total } \\
\text { Women Members }\end{array}$ \\
\hline 1999 & 543 & 48 & 8.8 \\
2004 & 543 & 45 & 8.1 \\
2009 & 543 & 59 & 10.9 \\
2014 & 543 & 61 & 11.2 \\
\hline
\end{tabular}

Source: Election Commission of India (quoted from Vijayakumari and Rao, GJRA Vol 3, Issue 8, August Special Issue 2014

The low number of women candidates nominated by political parties in the 2014 legislative election suggests that not much has changed since 2009. Many political parties have supported for increasing women's participation in electoral politics at the national level, but often this has not materialised in more significant opportunities for aspiring women candidates. Gender quotas have existed in local councils since the mid-1990s, but no gender quota exists at the national level [6]. The reasons are the first tradition; it means that the more traditional gender roles are women as caregivers and housewive become absolute. Second, the domination of power structure. It is not purely about the man. So, it is about the dominant class whomever it is. They are the ruling class of the power structure. Third, money makes the world go round for politicians in India. Fourth, education is more important for women contestants because in India only $-53 \%$ of candidates are graduates or above, compared with $48 \%$ for male candidates the overall average for all candidates is $48 \%$ [7].

\section{Supporting Program to Advance Gender Equality in Politics through Social Media}

To sustain progress towards gender equality in parliaments, UNDP pursues gendermainstreaming and gender-targeted approaches: The gender-mainstreaming approach refers to the integration of a gender dimension into broader parliamentary mechanisms. The gendertargeted approach involves activities that target men or women - such as supporting parliamentarians and politicians to establish a faction or informal network on combating violence against women, helping women parliamentarians with public speaking, or ensuring that men contribute equally to the adoption and implementation of parliamentary policies and practices for gender equality [8].

There are five important programs for supporting gender equality in politics. First, to support mentoring by a more experienced member of parliaments and women in politics of less experienced colleagues to advance gender equality in parliamentary and other governance processes. Sharing experiences with colleagues is needed to improve the quality of parliamentarians or politicians. Second, support women's networks in parliament to collaborate with women in local or central governance. It means that the network between the legislative and the executive is required to build the nation's progress. Third, facilitate the exchange of best practices on the work of women's networks and gender-sensitive policymaking, including the use of tools to design gender-sensitive legislation. Then, it makes women's interests can be created and programmed in development policies. Fourth, promote regional networking of women parliamentarians. That is important because the network is the capital to strengthen the presence of female politicians at the regional level. Fifth, facilitate leadership, media and public relations training to help women member of parliaments to 
develop critical public speaking, debate and negotiation skills, and the ability to engage with the media to build public support for gender equality in politics and society [9].

Out of the five programs mentioned above, a formula can be formulated to achieve the program, that is, through the media. Social media are a manifestation of communication technology that is increasingly used to interact and disseminate information. Social media is about networking and communicating through text, video, blogs, pictures, status updates on sites such as Facebook, MySpace, LinkedIn or microblogs such as Twitter [10]

Access to social networks associated with the digitisation of information becomes the ability to reach audiences and users. The central element of social networks consists of some elements. First, social networks include different social channels and become the primary Internet channel. Second, social networks change over time, which means that social networks continue to grow. Third, participatory social networks. "The audience/audience" has the right to speak is considered creative so that it can provide comments [11].

Through social media, users of individual social networks, groups and institutions can act as communicators and recipients of communication in cyberspace. The flexibility in the use of social networks is not limited to the social, economic and political situation of society. About the five previous programs, parliamentarians and politicians can share experiences and raise awareness of gender equality for their colleagues, including the public. Through social networks, social networks between parliamentarians and the local and central government will be more developed. Through social networks, this will be facilitated through the exchange of gender-sensitive best practices, as well as a means tool to strengthen parliamentarians and increase their level.

It is undeniable that social media can transmit messages to the public or other users of social networks due to the support of a communication technology capable of reaching a broader and faster public. Many aspects of the media become important in political life. First, coverage is comprehensive in the dissemination of public information, which can cross regional (geographical) boundaries, age, gender, socioeconomic status (demographic), differences in understanding and orientation. Becoming a mediating political problem is a common concern in various places and circles.

This function marginalises the coverage of the popular media, which requires a long process and verifies the balance of the information from the sources of reliable messages. Regarding coverage, social networks can be used to create a network of political contacts between parliamentarians and their constituents to provide a political perspective of a fair gender life for the state. Attachment to the political class should be used among users of social networks to raise awareness about gender equality in politics.

\section{Conclusion}

In both Indonesia and India, to raise awareness about gender equality in politics, politicians must create political networks or contacts with the public through social networks with content that supports gender equality in politics.

\section{Acknowledgements}

I gratefully acknowledge that the research was financially supported by The Ministry of Research, Technology and Higher Education of the Republic of Indonesia.

\section{References}

[1] Wardono E, "Strengthening Women's Political Participation in Indonesia”, Medan, 2 October 2002. 
[2] Kurniaty, Evi Yunita,"Affirmative Action: Reservation Seats Untuk Perempuan di Parlemen India". Jurnal Ilmu Pemerintahan dan Sosial Politik 3 (2), pp. 187-196, 2015.

[3] Crocby, Faye J, Iyer, Aarti, Sincharoen, Sirinda, “Understanding Affirmative Action”. Annu. Rev. Psychol. pp. 587. 2006.

[4] Macionis, "Sociology”, New Jersey:Englewood Cliffs:.pp. 344. 1991.

[5] Vijayakumari and Rao, "Women's Political Participation in India”.GJRA (Global Journal of Research Analysis) Vol 3, Issue 8, August Special Issue. pp 3. 2014.

[6] Vijayakumari and Rao, "Women's Political Participation in India”.GJRA (Global Journal of Research Analysis) Vol 3, Issue 8, August Special Issue. pp 4. 2014.

[7] Vijayakumari and Rao, "Women's Political Participation in India”.GJRA (Global Journal of Research Analysis) Vol 3, Issue 8, August Special Issue. pp 4. 2014.

[8] “Strengthening women's political participation: Highlights of the impact of women's parliamentary networks in Eastern Europe and Central Asia", the United Nations Development Programme UNDP Istanbul Regional Hub. pp 5 .2016.

[9] "Strengthening women's political participation: Highlights of the impact of women's parliamentary networks in Eastern Europe and Central Asia", the United Nations Development Programme UNDP Istanbul Regional Hub. pp 8.2016.

[10] Alejandro, Jennifer, "Journalism In The Age of Social Media”, University of Oxford, Reuters Institute for the study of Journalism: Hilary and Trinity Terms \& Thomson Reuters Foundation. pp 3. 2010.

[11] Evans, Dave. Social Media Marketing An Hour A Day, Canada: Wiley Publishing, Inc. pp 34. 2008. 